\title{
The Nullity of Non-Remarriage Condition in the Legal Mind and Judicial Decisions of the Islamic Republic of Iran Civil Law
}

\author{
EbrahimTaghizadeh $^{1} \&$ Seyed Ali Tabatabaee Far $^{2}$ \\ ${ }^{1}$ Central Organization of Tehran Payam Noor University, Iran \\ 2 Department of law, Neyshabur Branch, of Islamic Azad University, Neyshabur, Iran \\ Correspondence: Seyed Ali Tabatabaee Far, Department of law, Neyshabur Branch, of Islamic Azad University, \\ Neyshabur, Iran. E-mail: s.a.tabatabaeifar@gmail.com
}

\author{
Received: September 4, 2016 Accepted: October 2, 2016 Online Published: December 29, 2016 \\ doi:10.5539/jpl.v10n1p127 URL: http://dx.doi.org/10.5539/jpl.v10n1p127
}

\begin{abstract}
This study investigates the validity of man non-remarriage condition in Iran Civil law by using the judicial and legal analysis in descriptive and analytical method. The purpose of this study is to resolve some of the ambiguities surrounding this condition of the marriage document that can be used for the Bureau of family Court, lawyers, and other legal entities. Our survey shows that although there is no clear wording of the law in the Iran legal system. According to the judicial decisions and some of the Articles such as 959 and 942 in Civil law and the 1201/7 vote of the Supreme Court, it seems that non-remarriage condition in Iran Civil law is considered as instances of general negation and void, but its nullity does not impair the validity of the marriage.
\end{abstract}

Keywords: condition, marriage, remarriage, man, rights, Iran

\section{Introduction}

Today, one of the conditions about which legal experts have a disagreement between the nullity or validity of it is the man non-remarriage condition; because some Iranian women want to prohibit their spouses from remarriage by provision this condition in the marriage document or other necessary contracts. That causes confusion among respected officers and judges and makes us investigate the now- remarriage situation in the legal mind and judicial opinions.

\section{History}

Amily, as a natural group is the oldest and the most important social group that existed from the beginning of human life (Safai and Imami, 2010: 13), so the origin of marriage dated to the beginning of human life. Polygamy was proposed from the ancient times in different communities and it hardly is found for women in earlier societies and present ethical society, while this issue is seen for men, not only in the past but also today (Roshan, family law, 2011: 184). Historically, in Iran before Islam, the principle of polygamy was at the time of the Sassanids, the man could have several wives depending on his financial ability (Motahari, The women law in Islam, 2011: 292). Except for Iran, the polygamy was in other lands like Arabian Peninsula before Islam, and Islam couldn't eliminate all at once. Therefore, Islam is removed the abuse of it by legislation and recommended polygamy only under certain conditions, according to social interests (Roshan, Family Law, 2011: 185).

In Iran legal system, Article 23 of the current family protection draft bill (Act 2012-13) had made the polygamy bound by the court's permission related to the marriage and non-remarriage condition. But the existence of this article in the mentioned bill faced with some reactions that caused the elimination of this section by the Islamic Consultative Assembly, and the current family protection draft law had approved without this article, but this question remains that how is the legal status of remarriage condition.

\section{Definition}

\subsection{Marriage Contract}

The word marriage means close and grafting and tying (Moeen, 2003: under the terms of the marriage contract). In Iran civil law, Articles 183 and 10 discussed the definition of the wedding, but article 183 has some drawbacks (To read more: Katoozian, 2010: Article 183). Therefore, the Iranian lawyers define the marriage contract as the agreement between two or more wills that is done to create legal effects (Katoozian, 1997, vol. 1: 24-16). 


\subsection{Condition}

The condition means requirement and obligation to something (Ghoreshi, Bita: under this word), but there is no legal definition of it. By reading the legislative articles can understand that condition is a requirement and commitment that set beside the principal responsibility within the marriage contract. Iranian lawyers believe the marriage contract in the general absolute mean as promise and determination, whether it is within marriage contract or not (Katozian, 1997: V. 1: 108). And they also believe that the condition is a matter on which the occurrence or impact of the specific rights action or event to be provided depends (Katozian, 1197, vol. 1: 114-112).

\subsection{Remarriage}

The word marriage means (join), marry a woman and intercourse (Ghoreshi, Bita: under the word marriage); (Qureshi, 1973: under term marriage). So remarriage means marry with additional women and intercourse with another woman. There is no definition of marriage in Iran and France law, but Iranian lawyers believe marriage as a deal by which a man and a woman become unique and make a family (Safaee and Imami, 2010: 23).

\subsection{Right}

In Literally science, right means truth, right, justice (Moeen, 2003: under the word marriage) and lies against the void (Johari, 1407: vol. 4, p 1420). There is no clear definition of right in the legislation. But, by reading the articles of civil law, the right can be understood as suggested matters in law that people are allowed to change and retire it, in which right will be in front of the sentence that is consistent with the definition of Jurists (Emami, 1996, vol. 1: 125).

\section{Non-remarriage Condition Nullity in Lawyers Mind}

In Iranian legal system, we are facing with three analyses of non-remarriage condition nullity:

A) A group of lawyers knows non-remarriage condition nullity against Iran moral and religious rules and customs, according to Article 942 of Iran Civil law. This bunch of lawyers believes that man can have several women, and in Iranian law, polygamy is the inalienable right of man. Thus the non-remarriage condition is contrary to existing legislation and sentenced to nullity, but the marriage contract will still be valid (Imami, 1996, vol. 4: 366).

- $\quad$ Regarding the opinion of these lawyers, this criticism is proposed that Article 942 only determines the legal status of patrimonial division in inheritance and doesn't know remarriage as a right for man. But, in our opinion, this criticism is not true; because there is no need to restrict the lawyer to the law and implicit interpretations from the text of the law is not valid.

B) A group of Iranian lawyers has considered the polygamy as inalienable rights of a man (Katozian, 2006: V. 1, 268). Based on Article 959 of the Iran Civil law, which rejects this negation, and considers non-remarriage condition as general denial and voids this condition, but in the opinion of these lawyers, the nullity of this state prejudice the validity of the marriage contract (Safari and imams, 2010: 61).

- It seems that the argument of these lawyers is logical, because, by careful consideration in this law realize that remarriage is legal rights of a man. For example, according to Article 16 of the family protection law (approved in 1974), some lawyers believe that remarriage is the civil right of a man in this Article (Katozain, 2006: vol. 1, 270-268). In our opinion, according to Article 21 of the family protection law (2012-13), which has presented the perpetual marriage as the basis of the household. Also grants legitimacy to the temporary marriage, and since temporary marriage is a kind of marriage and according to the judiciary advisory profile 09.05.1381 No. 3902/7, remarriage will also be established by temporary marriage (Education Department of the Judiciary, 2008: vol. 2, p. 17). It can be concluded that according to Article 21, the remarriage right will be implicitly for men who have legal conditions.

- According to this bunch of lawyers' view, this question is proposed: if the non-remarriage condition expels the general status to not be the subject of Article 959 of the Civil Law. For example, if the remarriage right of a man restricted in a way that he is not allowed to remarry at an appointed time (10 years) with Ms. A and Ms. B and Ms. ... (individual persons), how is the legal status of this condition? In response, the condition will be true in this case, because negation has no drawback in details and Article 959 is the observer of negation in general.

C) A group of lawyers void non-remarriage condition relying on the idea (MASHHUR) of Imam (Shia) Jurists (MohagheghDamad, 2005: 330. Because (MASHHUR) of Imam (Shia) Jurists has believed that non-remarriage condition is unlawful, and they are believed to the nullity of the non-remarriage condition and the validity of the marriage contract (Bohrani, 1408: Vol 24, p 525). 


\section{Nullity of Non-Remarriage Condition according to Supreme Court}

A) The vote No. 1201/7 of file class 7/21/901 of the Supreme Court have known the remarriage as a lawful right for every Shiite Muslim (Bazgir, 2010: vol. 3, p. 208 and 209).

- According to the above vote, the theory of warrant marriage being rejected and marriage rights will be considered. Despite the extinction and transfer capabilities of rights are its obvious feature, there are some exceptions. Some laws are indefeasible and non-transferable for some interests, in this regard, (MASHHUR) Imam (Shia) Jurists have presented some divisions of the rights (YazdiTabatabai, 1999: V.1.56), (Bahr al-Ulum, 1983 , vol. 1, p. 16 onwards). So, marriage right will not be dismantled; thereby non-remarriage condition is also invalid.

B) The vote number 176-8 / 11/68 of file class 27-68 of the Supreme Court; by the deduction of the contrary concept of Articles 1048 and 1049 of Iran civil law, the remarriage is permitted with regards to some conditions.

- The pronounced judges of this vote have taken the permission of polygamy according to the contrary principle of these two articles of the civil law. Because it is determined by the opposite principle of these Articles that with the existence of one spouse, provided that there are no obstacles referred to these Articles, the man can remarry, and polygamy implicitly assumed to be in the Iranian Civil law.

Article 1048: Tucked between two sisters is forbidden, even though the contract is interrupted.

Article 1049: No one can marry with his brother- or sister-in-law's daughter, except with the permission of his wife.

\section{Conclusion}

There are 12 conditions within the marriage contract in marriage documents as default, which will be applicable by parties' signature and made some commitments. But, today these conditions have not been believed enough for some couples, and they want to put more conditions in within marriage contract. Therefore, some Iranian women who are looking for a non-remarriage condition for their husbands reflect non-remarriage condition within marriage contract or other necessary contracts.

Any condition that has no legal drawback can be mentioned within marriage contract and even within other necessary contracts legally. But our survey shows regard to it that remarriage is considered as the civil right of every man in the Iranian legal system. This issue is taken implicitly from individual articles of the Civil law, including Article 942 and the contrary principle of Article 1048 and 1049 and Article 16 of the Family Protection Act (approved in 1974) as well as Article 21 of the Family Protection Act (approved 2012-2013) and Iran Supreme Court vote No. 1201/7 and 176-8/11/68. Then, the non-remarriage condition is mounted as a negation of law generally, and general negation of law is not allowed according to Article 959 of the Civil law that is a peremptory norm, so, the non-remarriage condition would be null and void, but the nullity of this condition does not prejudice the validity of marriage.

\section{References}

Bahr al-Ulum, S. M. (1984). Balghat al-faghih (Vol. 4). Maktab al-Sadegh publication, Tehran.

Bazgir, Y. (2010). Judgments of the Supreme Court in Legal Affairs (Vol. 3). Forest publication, Tehran.

Bohrani, Y. B. A. (1408). Alhadaegh al-Nazereh (Vol. 25). House of Islam publication of Qom Teacher's community, Qom.

Department of Education Judiciary. (2008). Iran's Judicial Procedures relating to family Courts (Vol. 5). Forest Publication, Tehran.

Imami, S. H. (1998). Civil Rights (Vol. 6). Islamia Publications, Tehran.

Katozain, A. N. (1997). Civil rights, Public Contract Regulations (Vol. 5, 3rd ed.). Enteshar Limited Company Publication, Tehran.

Katozian, A. N. (2006). Civil Rights: Family (3rd ed.). Enteshar Limited Company Publication, Tehran.

Katozian, A. N. (2010). Legal actions (contract-Unilateral legal act) (2nd ed.). Enteshar Limited Company Publication, Tehran.

Katozian, A. N. (2010). The Civil law in the Current Legal System (24th ed.). Mizan Publication, Tehran.

Moeen, Mohammed: Persian Dictionary, Neda Publication, Tehran, First Edition, 2003.

Mohaghegh Damad, S. M. (2005). Legal study of family law. Center of Islamic Sciences Publication, Tehran. 
Motahari, M. (2011). Women Rights in Islam. MullaSadra, Tehran.

Qureshi, S. A. A. (1973). the vocabulary of the Qur'an (Persian) (Vol. 7). Drolketabe al-Islamia, Tehran.

Qureshi, S. A. A. (n. d.). MateriaNahj al-Balagha (Persian) (Vol. 2, 1st ed.). Mecca Cultural Institute Publication, Tehran, Bita.

Roshan, M. (2011). Family Law (1st ed.). Forest Publication, Tehran.

Safai, S. H., \& Imami, A. (2010). A brief of family law (24th ed.). Mizan Publication, Tehran.

Tabatabai Yazdi, M. K. (1999). Almakaseb margin (Vol. 2). Esmaeeilian al-Taba-e Publication Institute, Qom.

\section{Copyrights}

Copyright for this article is retained by the author(s), with first publication rights granted to the journal.

This is an open-access article distributed under the terms and conditions of the Creative Commons Attribution license (http://creativecommons.org/licenses/by/4.0/). 